\title{
Gender, Judicatory Respect and Pastors' Well-Being in Closing Churches
}

\author{
Gail Cafferata ${ }^{1,2}$ (D)
}

Received: 18 September 2019 / Accepted: 9 May 2020 / Published online: 23 May 2020

(c) Religious Research Association, Inc. 2020

\begin{abstract}
This study of over 130 clergy in five old-line Protestant denominations (Episcopal, Lutheran, United Methodist, Presbyterian and UCC) who dissolved their congregations examines the relationships of gender, judicatory respect and pastors' wellbeing in their experience of closing a church and vocational transition afterwards; respondents completed a written survey and most also participated in in-depth interviews. Survey results show significant gender differences in the experience of respect from and satisfaction with relationships with the middle administrative part of the wider church called here the judicatory (e.g., synod, conference, diocese or presbytery), and with the experience of stress after their churches closed. Women clergy experienced greater loneliness and isolation, financial strain and thinking that closure affected their job search; their job search was also significantly longer than that of men. Respectful judicatory relationships are negatively related to many but not all vocational stresses. Comparisons with the experience of secular professionals suggest the stigma of closing a church adversely affects women clergy's vocational journey more than men's. The paper closes with implications for judicatory support of clergy leading churches to closure.
\end{abstract}

Keywords Clergy · Wellness · Congregation · Stress · Health $\cdot$ Church decline · Church closing · Practical theology · Protestant denominations · Gender · Women · Religious coping $\cdot$ Social support $\cdot$ Living human web $\cdot$ Sociology of religion

Gail Cafferata

revgailc@gmail.com

1 Center for Practical Theology, Boston University School of Theology, Boston, MA, USA

2 Santa Rosa, CA, USA 


\section{Introduction}

The challenges and rewards of clergy serving Protestant churches spring from the intersection of their divine call to ordained ministry with the sacred communities called "church" (both local and wider), and the broader social culture in which pastors and their congregations are embedded. A pastor's experience of vocational risks like precarious finances, church conflict, and rural isolation, as well as vocational rewards like deepened faith in God, collaborative relationships with church members, and respect by colleagues and superiors such as bishops, depend not only on the presence of God, but also the commitments and practices of institutional systems within which they work, not only congregations, but also denominational institutions.

Social scientists know little of how the wider, administrative bodies that coordinate local congregations, called judicatories, affect a pastor's experience of vocational challenges and rewards. These middle administrative bodies (such as dioceses or synods) are both the "body of Christ" and modern bureaucracies. As such, they are hybrid structures with inherent tensions between communal norms such as equality, transparency and respect, and institutional demands such as a hierarchy of authority, effectiveness, efficiency and sustainability. As well, a diverse mosaic of inner-city/rural, large/small, majority-Anglo/majority-ethnic, working-class/white collar, theologically conservative/progressive congregations in the same body may strain a judicatory's capacity to support pastors serving vulnerable churches (Cafferata 2020). Although earlier research has documented a gender gap among clergy in compensation, full-time placements, attainment of higher-level leadership positions, and acceptance of their leadership, we still do not understand whether access to judicatory, as well as congregational support, differs among men and women pastors serving congregations that eventually close (Zikmund et al. 1998; Price 2009).

This paper draws on survey and interview data from a five-denomination national study of pastors who had the experience of closing their churches (Cafferata 2017). This point of church crisis and vocational vulnerability offers a unique opportunity to examine whether career challenges such as spiritual or emotional stress, health issues, or access to resources such as financial or spiritual support from a judicatory differ among women and men. Further, it enables us to examine how the demise of their congregation subsequently affects the vocations of men or women clergy, for example, whether they are equally able to secure their next position and experience satisfaction with their new ministries and lives.

This research is important because the rate of church decline is rising across mainline Protestant denominations and more pastors, both men and women, will experience this ministry in their vocation (Voas and Chaves 2016; Roozen 2010; Pew Research Center 2019). For example, the Episcopal Church lost almost a quarter of its members between 1986 and 2010 (Goodhew 2017). Old-line Protestant churches like those in this study are becoming older and more fragile as congregations fail to replace themselves with newer generations (McKinney 2012; Funk and Smith 2012). Economic displacement associated with the Covid-19 pandemic may accelerate this trend. 


\section{Literature Review}

Even when not closing a church, serving as a pastor can be challenging (Chaves and Eagle 2016; Ellison et al. 2009; Francis et al. 2011; Lewis et al. 2007; Pepinster 2018; Proeschold-Bell and Byassee 2018). Serving when a church's future is threatened by congregational aging, declining income, culturally shifting neighborhoods, and the inability to replace leaving or dying members with young families is even more so (Bendroth 2018; Berry et al. 2012; Darling et al. 2004; Ellison et al. 2009; Francis and Brewster 2012; Gledhill 2015; Peyton and Gatrell 2015; Rudgard 2017; Willimon 2013; Wuthnow 1997; United Church of Christ 2015; Gaede 2002; Irwin 2014; Olson 2016). In these demanding circumstances, the "living human web" of supportive relationships should be important in buffering clergy's spiritual and emotional stress and nurturing wholeness (MillerMcLemore 2018). A wholistic health approach posits that this "living human web" of personal and professional support affects clergy health (Proeschold-Bell et al. 2011).

Although women in historic Protestant denominations have been ordained for decades, women clergy must work harder than men to obtain a position, keep a position, get equal pay, and get promoted (Greene and Robbins 2015; Froschauer 2014; Chang 1997; Executive Council's Committee on the Status of Women et al. 2009; Hoegeman 2017; Hughes 2018; Lehman 2001; Zikmund et al. 1998). Similarly, in non-religious job sectors, a cultural presumption of male superiority or dominance has been shown to affect hiring, job evaluation and promotion, pay, and access to in-group and mentoring supports in occupations such as nursing, science, law, medicine or business (Heilman 2012; Eagly and Heilman 2016; Carli and Eagly 2001; Vial et al. 2016; Lerchenmueller and Sorenson 2018).

In secular occupations, roles that require a high degree of agentic behavior such as authoritative decision-making, commitments to effectiveness and efficiency, self-advocacy and emotional distance are more difficult for women to negotiate successfully (Ridgeway 2011; Zheng et al. 2018), resulting in greater job stress. In the profession of ministry, women the risk being called "cold" or "aggressive" when they exercise structural authority. Like women in other occupations, women pastors may be more inclined to exercise charismatic or inspirational personal authority and to see themselves as empathic, transformational leaders (Brescoll 2016; Ramsay 2000; Zikmund et al. 1998). A transformational leadership style is built on relationships of respect, trust and communality; it is emotionally expressive, inspires motivation for others to participate and contribute, and values the development and mentoring of community members.

In contrast, prevailing gender norms make it easier for male clergy to exercise a transactional or laissez-faire leadership style where relationships are more formal, exchange-based, and focused on task completion. One study found that nearly a third of women pastors view their role primarily as one of empowering laity to implement decisions that laity have made, whereas only $10 \%$ of clergy men chose this style (Carroll 2006). Research has confirmed that women leaders are seen as more effective when they exercise both inspirational motivation (seen 
as agentic) and individual consideration (that is seen as communal) (Zheng et al. 2018). This study therefore expects women pastors may be more likely than men to be disappointed when denominational colleagues and superiors fail to respect their dignity by not accepting their identity, including them as much as their male colleagues in professional work, being fair, understanding them, recognizing them, or, in other words, when judicatories fail to exercise inclusive, transformational leadership.

Failure to accept their pastoral identity, or unfair demeaning of their competence may be a unique source of stress for women pastors. For example, managerial literature has shown that women walk a "razor's edge" in balancing expectations for agentic behavior with cultural expectations for women's communality such as being caring, participatory, other-serving, and approachable (Zheng et al. 2018). Evaluations of competence are shaped by a leader's capacity to exercise both agentic and communal behavior; traditional gender expectations assume women's agency and competence to be lower than men's, with women being less likely to be perceived as leaders despite the same qualifications; when they succeed, women are more likely than men to attribute it to hard work and less likely to attribute it to innate ability (Ridgeway 2011; Lerchenmueller and Sorenson 2017; Pickett 2019). When things aren't going well, as in the throes of church closure where there is grief and even conflict about what to do and how to do it, a cultural presumption of male dominance or superiority may be able to buffer the attribution of failure or incompetence to male but not female clergy, especially in denominations such as the Church of England, the Episcopal Church, and others where formal hierarchical leadership has been historically male (Greene and Robbins 2015; Ridgeway 2014).

Although one study found women pastors find greater social support in their congregations and among colleagues and the church hierarchy than men (McDuff and Mueller 1999), that research was confined to clergy in two non-hierarchical denominations (DOC and UCC). Other studies show that women pastors find less support in their work than men. For example, women priests in the Church of England reported overt and hidden congregational hostility to their leadership as well as a lack of respect among colleagues in the wider church such as being talked about behind their backs, openly criticized, belittled in public, overly scrutinized, and not being listened to (Greene and Robbins 2015). They reported being placed in appointments at a higher risk of failure as well as in congregations lacking empathy for the constraints of motherhood and work-life balance. In the U.S., a national study of Methodist clergy found women pastors more likely than men to report occupational stress, hostility of church environment and perceived stress (Wespath 2019). In the Episcopal church, men reported greater assistance from Bishops in their job search than women, and gender inequalities persist in income, access to senior positions, and the ability to achieve work-life balance (Price 2009).

An essential quality of pastoral relationships with congregations and judicatories, the "living human web," is mutual respect. Respect is a nearly universal dimension of ethics. Respect for the other, as in the golden rule ("Do unto others and you would have them do unto you"), is a foundational value in the fields of education (Deutsch and Jones 2008), the law (Lawrence-Lightfoot 2000), nursing (Parse 2006), medicine (Sarsons 2017), feminist studies (Farley 1993), business (van Quaquebeke and 
Eckloff 2010), and entire societies (Dyck 1977). Respect is key to reconciliation efforts as described in the "dignity" model of Hicks (2013), spanning dimensions such as acceptance of identity, inclusion, safety, acknowledgement, recognition, fairness, benefit of the doubt, understanding, independence and accountability. Following this model, this study measured clergy satisfaction with these dimensions of respect from their congregations and their judicatories.

Although mutually respectful relationships may deter the formation of shame and stress among clergy closing churches (Lawrence-Lightfoot 2000), "second generation gender bias" against women, that is, widespread "cultural beliefs about gender as well as workplace structures, practices and patterns that inadvertently favor men," (Ibarra and Petriglieri 2015) may intrude in the church, increasing stress for women clergy serving a closing congregation. The persistence of gender bias even after acceptance of women into professions such as science has been well noted (Pickett 2019). Such bias may shrink support by judicatories as well as congregations considering them for positions after their church closes. In the heat of conflict or the pain of grief, cultural and structural resistance to women's leadership may prove stronger than any theological commitment to dignity, respect and fairness or, for that matter, bureaucratic norms of efficacy, efficiency, and accountability.

On the basis of previous research, this study hypothesizes that:

1. Satisfaction with respect from their congregations and judicatories will differ by gender, with male pastors being more satisfied than women pastors;

2. Lower satisfaction with respect from their congregations and judicatories will be associated with the experience of "worsening health" while serving the church that closes as well as the experience of a difficult, even tragic, closing, measured by a pastor's description of it as like "Good Friday" or "Holy Saturday," rather than a "reflective" church season (Advent, Lent) or a "festive" church season (Christmas, Epiphany, Easter, Pentecost, All Saints).

3. Satisfaction with respect from congregations and judicatories will be associated with mental health of pastors one to three years post-closure (when the written survey was completed).

4. The experience of overall vocational stress such as difficulty finding a new position will be associated with lower satisfaction with mutually respectful relationships with congregations and judicatories.

5. Women will have more difficult vocational trajectories following a church closure than men, i.e., longer job search time, less support from judicatories in their job search, less satisfying relationships with their judicatories after closure.

\section{Methods}

This study examines the experiences of a universe of women and men clergy in five mainline Protestant denominations (Episcopal, Lutheran, Methodist, Presbyterian and United Church of Christ) who closed their churches over a span between 2010 and 2013, depending on the denomination. After pastors' names and contact information were received from the national research offices of each of these 
denominations, 7-page surveys were mailed in 2014-2105 (with postage-paid envelopes), with follow-up surveys and reminder postcards at appropriate intervals. Surveys were completed by 132 (42\%); there were no significant differences in response rates by gender; the only non-response bias was race, with non-whites less likely to respond than whites.

Table 1 Characteristics of independent variables and dependent variables

\begin{tabular}{|c|c|c|c|}
\hline Variable & Measure & $\mathrm{M}(\mathrm{SD})$ & $\begin{array}{l}\mathrm{R} \text { with overall } \\
\text { vocational stress }\end{array}$ \\
\hline \multicolumn{4}{|l|}{ Pastor independent variables } \\
\hline Age & Years & $60.00(10.80)$ & $-0.41 * * *$ \\
\hline Gender & $1=$ male, $0=$ female & $0.59(0.49)$ & $-0.22 *$ \\
\hline Married & $1=$ yes, $0=$ no & $0.83(0.37)$ & $-0.17 *$ \\
\hline First or second call & $1=$ yes, $0=$ no & $0.31(0.46)$ & $0.20^{*}$ \\
\hline Bi-vocational & $1=$ yes, $0=$ no & $0.31(0.46)$ & -0.03 \\
\hline Multi-point appointment & $1=$ yes, $0=$ no & $0.44(0.50)$ & $-0.30 *$ \\
\hline Pastor expects growth & $1=$ yes, $0=$ no & $0.86(0.70)$ & 0.05 \\
\hline $\mathrm{RCOPE}+(7$ items $)$ & Cronbach's $\alpha=0.84$ & $18.78(4.65)$ & $0.26 * *$ \\
\hline Pastoral Challenges (10-item scale) & Cronbach's $\alpha=0.84$ & $25.45(6.20)$ & $0.36 * * *$ \\
\hline Pastoral Stress (5-item scale) & Cronbach's $\alpha=0.82$ & $11.00(3.74)$ & $0.66 * * *$ \\
\hline Perceived Health (post-closure) & $\begin{array}{l}1=\text { poor, } 2=\text { fair, } 3=\text { good }, \\
4=\text { very good, } 5=\text { excellent }\end{array}$ & $3.65(0.94)$ & -0.12 \\
\hline Satisfaction with life (2-item scale) & Cronbach's $\alpha=0.79$ & $7.06(1.20)$ & $-0.40 * * *$ \\
\hline $\begin{array}{l}\text { Satisfaction with new ministry } \\
\text { (3-item scale) }\end{array}$ & Cronbach's $\alpha=0.81$ & $10.33(1.85)$ & 0.08 \\
\hline \multicolumn{4}{|l|}{ Pastor dependent variables } \\
\hline $\begin{array}{l}\text { Reported "My health worsened" } \\
\text { when serving }\end{array}$ & $1=$ yes, $0=$ no & $0.30(0.46)$ & $-0.56 * * *$ \\
\hline $\begin{array}{l}\text { Closing like Good Friday/Holy } \\
\text { Saturday }\end{array}$ & $1=$ yes, $0=$ no & $0.35(0.48)$ & $-0.34 * * *$ \\
\hline $\begin{array}{l}\text { Perceived mental health (5-item } \\
\text { scale) post-closure }\end{array}$ & Cronbach's $\alpha=0.84$ & $18.57(3.25)$ & $-0.23 * * *$ \\
\hline $\begin{array}{l}\text { Overall vocational stress post-closure } \\
\text { (6-item scale) }\end{array}$ & Cronbach's $\alpha=0.89$ & $13.42(6.67)$ & 1.00 \\
\hline \multicolumn{4}{|l|}{ Congregation independent variables } \\
\hline Congregational conflict & $1=$ little or none to $6=$ greatest & $2.53(1.39)$ & $0.24 * *$ \\
\hline Emotional skill (6-item scale) & Cronbach's $\alpha=0.81$ & $20.55(5.24)$ & $-0.22 *$ \\
\hline $\begin{array}{l}\text { Lay initiative in closing the church } \\
\text { (2-item scale) }\end{array}$ & Cronbach's $\alpha=0.88$ & $0.79(2.45)$ & $-0.19 *$ \\
\hline Congregational respect & Cronbach's $\alpha=0.96$ & $44.77(8.53)$ & $-0.32 * * *$ \\
\hline \multicolumn{4}{|l|}{ Judicatory independent variables } \\
\hline Polity (has Bishops) & $1=$ any, $0=$ none & $0.75(0.43)$ & -0.09 \\
\hline Appointment system & $1=$ yes, $0=$ no & $0.30(0.46)$ & $-0.23 *$ \\
\hline Judicatory expects growth & $1=$ any, $0=$ none & $0.42(0.50)$ & -0.06 \\
\hline Judicatory respect & Cronbach's $\alpha=0.98$ & $39.65(12.50)$ & $-0.49 * * *$ \\
\hline
\end{tabular}


Table 1 shows measures used in statistical analyses. Clergy variables include age, gender, marital status, church experience (first or second appointment vs. longer experience), whether the pastor had a multi-church appointment, whether they were bi-vocational, whether the pastor or the judicatory initially expected the pastor to "revitalize a congregation" and religious coping (positive RCOPE scale) (Pargament et al., 2001), and health post-closure.

Challenges when serving the church were measured by two variables-first, a ten-item Pastoral Challenges scale with dimensions such as: dealing with members' difficult emotions, initiating discernment, the process of discernment, the actual decision to close, disposition of church property, spiritual care of the congregation, and self-care, and a second, Pastoral Stress scale based on the question: "When you served the church that was closing, how often did you (Very often/Fairly often/Rarely/Never): Experience stress because of the challenges in that congregation? Feel lonely and isolated in your work? Have doubts about your abilities as a pastoral minister? Seriously think of leaving for a secular occupation? Seriously think of leaving for another type of ministry?".

To assess satisfaction with life and ministry one to three years after the church closed, two scales were used: Satisfaction with personal life, a two-item scale including satisfaction with family life and with personal life (rated on a scale: Very satisfied/Somewhat satisfied/Somewhat dissatisfied/Very dissatisfied), and Satisfaction with ministries is a 3-item scale including satisfaction with current ministry, effectiveness as a pastor in their present congregation, and relationships with members and leaders of your current church.

To assess congregational context, independent variables included the perceived level of conflict when the pastor entered the church, congregational laity and leadership initiative in closing the church, emotional skill of the congregation (6 items, "Members of congregations may express a range of emotions in the process of closing. How skillful were members in communicating:" Fear, Anger, Sadness, Tenderness, Acceptance, Gladness, rated on a 5-point scale "Inadequate to Excellent"), and congregational respect.

Both congregational and judicatory respect were measured with a series of 13 items derived from the "dignity" model (Hicks 2013). The two overall scales of Satisfaction with congregational respect and Satisfaction with judicatory respect (Very satisfied/Somewhat satisfied/Somewhat dissatisfied/Very dissatisfied) span a variety of dimensions shown in Fig. 2. Table 1 shows reliability coefficients. Binary judicatory independent variables included Polity (Bishops/none) and Appointment (vs. call) system.

Dependent variables included: "Health worsened," measured by "In your opinion, how did serving in this church affect your health? My health improved/My health remained stable/My health worsened/I don't know if it affected my health." Because it measured what happened when the pastor served the church, this was also an independent variable in several post-closure regressions of stress.

A binary variable indicating a closing experience like "Good Friday/Holy Saturday" was based on the question: "If the process of closing your congregation was like a church season or holy day, it would be: (Advent/Christmas/Epiphany/ 
Lent/Good Friday/Holy Saturday/Easter/Pentecost/Other: specify)." Pastors imputed their own understanding of these words.

A brief 5-item "Mental Health" scale was based on a series of questions used in another clergy survey (Carroll 2006). "The following questions are about how you feel and how things have been with you during the past four weeks. For each question, please give the one answer that comes closest to the way you have been feeling. How much of the time during the past four weeks: All of the time/Most of the time/ Some of the time/A Little of the time/None of the time: Have you felt calm and peaceful? Did you have a lot of energy? Have you felt downhearted and depressed? Did you feel worn out? Have you been happy?" Overall Vocational Stress Post-closure was a summary scale based on 6 questions (Table 2).

Multivariate analysis used backwards stepwise regression for two dependent variables: Mental Health and Overall Vocational Stress. Logistic regressions were used to assess fit for the variables "Health worsened," and "Good Friday/Holy Saturday." and A power test with $\mathrm{G}^{*}$ power demonstrated adequate sample size for all final regressions.

\section{Results}

In summary, the research shows that women clergy who experience the closing of their churches report are less satisfied with respect from their judicatories (but not from their congregations) than men clergy. Pastors reporting greater satisfaction with respect from congregations and judicatories are less likely to report that their "health worsened," a closing like "Good Friday," or "Holy Saturday," or to report poor mental health 1-3 years after the church closed. Further, their overall vocational stress after closing was lower. However, the correlation of judicatory respect with mental health (1-3 years post-closure) is attenuated by the inclusion of selfrated physical health and measures of satisfaction with current relationships with the "living human web" of family, colleagues and denominations. The study also demonstrates that among the vocational consequences of closing a church, a job search for women takes longer than men, is accompanied by women's greater reporting of

Table 2 Items composing overall vocational stress scale, by gender

\begin{tabular}{lll}
\hline When the doors of church closed, how much did you: & Women & Men \\
\hline $\begin{array}{l}\text { Experience stress because of the need to find another position? } \\
\text { Hear that closing a church would hinder your search for another pastoral posi- } \\
\text { tion?* }\end{array}$ & $32 \%$ & $21 \%$ \\
Think the experience of closing a church hindered your job search?** & 18 & 5 \\
Have a sense of shame? & 14 & 17 \\
Experience financial strain?** & 33 & 18 \\
Feel lonely and isolated?** & 42 & 32 \\
\hline
\end{tabular}

${ }^{*} p<0.05 ; * * p<0.01$ 
stigma associated with church closure, and is complicated by women's more difficult relationships with judicatory executives and colleagues in their new ministries.

Relating to Hypothesis 2, Fig. 1 shows that women clergy report consistently less satisfaction than men with respect from their judicatories, but not their congregations $(p<0.05)$. For example, nearly twice as many men as women were "very satisfied" with the judicatory's "speaking honestly with you." Women also lamented the lack of compassion, understanding and accountability they experienced from their denominational colleagues, that is, women perceive less inclusive, respectful leadership than do men among judicatory leaders.

This research explores whether mutually respectful relationships with colleagues and judicatory leadership are associated with pastors' experiences of personal and vocational outcomes. One possible consequence of work stress is worsening health (Hypothesis 2). Zero-order correlations reveal that gender is unrelated to worsening health but respect is significant $(p<0.001)$. Figure 2 shows that nearly seven in ten women clergy with low judicatory respect reported worsened health compared with no pastors with high judicatory respect, with a similar pattern for men (nearly six in ten compared with 12\%). Logistic multivariate regression of whether a pastor's "health worsened" while serving the church that closed reveals that younger pastors, and pastors experiencing lower respect from congregations and/or their judicatories were more likely to report worsening health (Table 3 ).

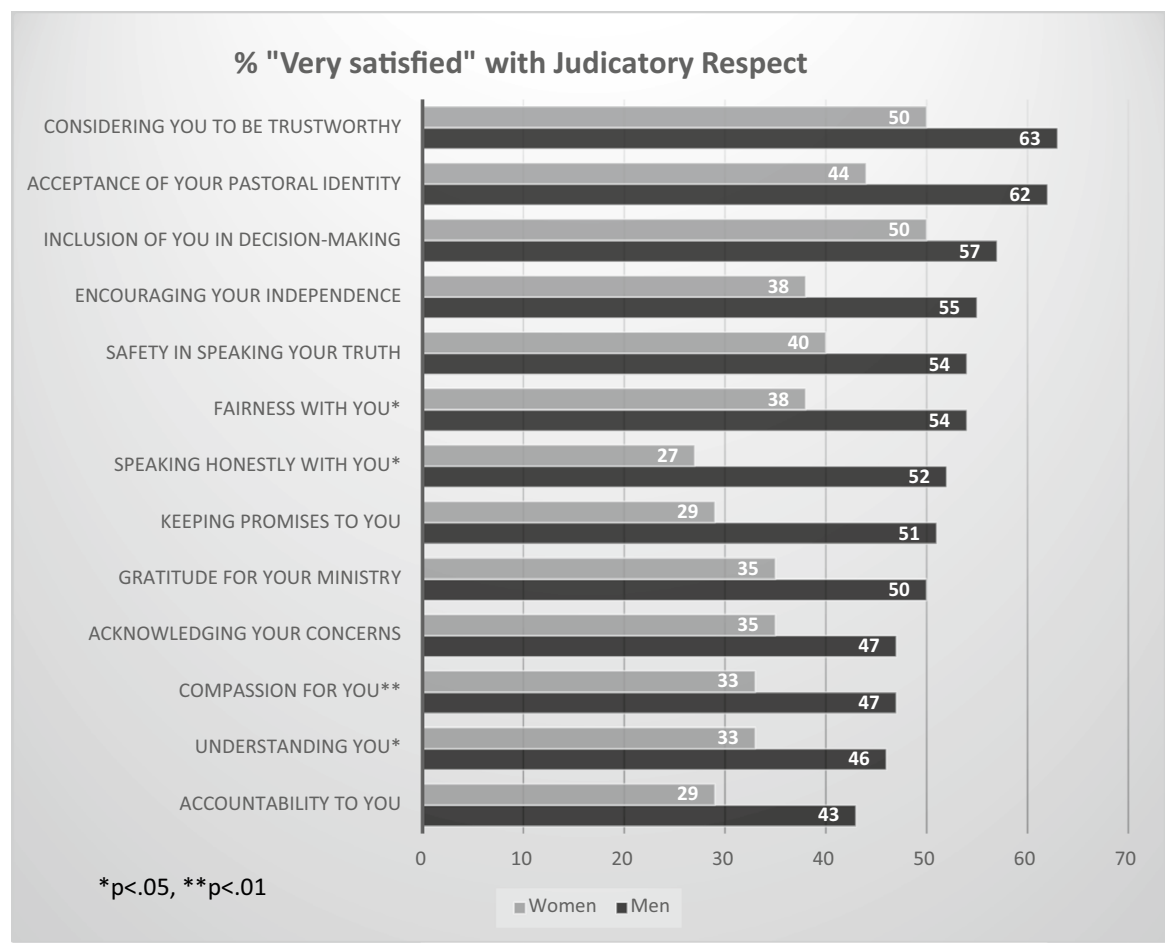

Fig. 1 Satisfaction with judicatory respect by clergy gender 


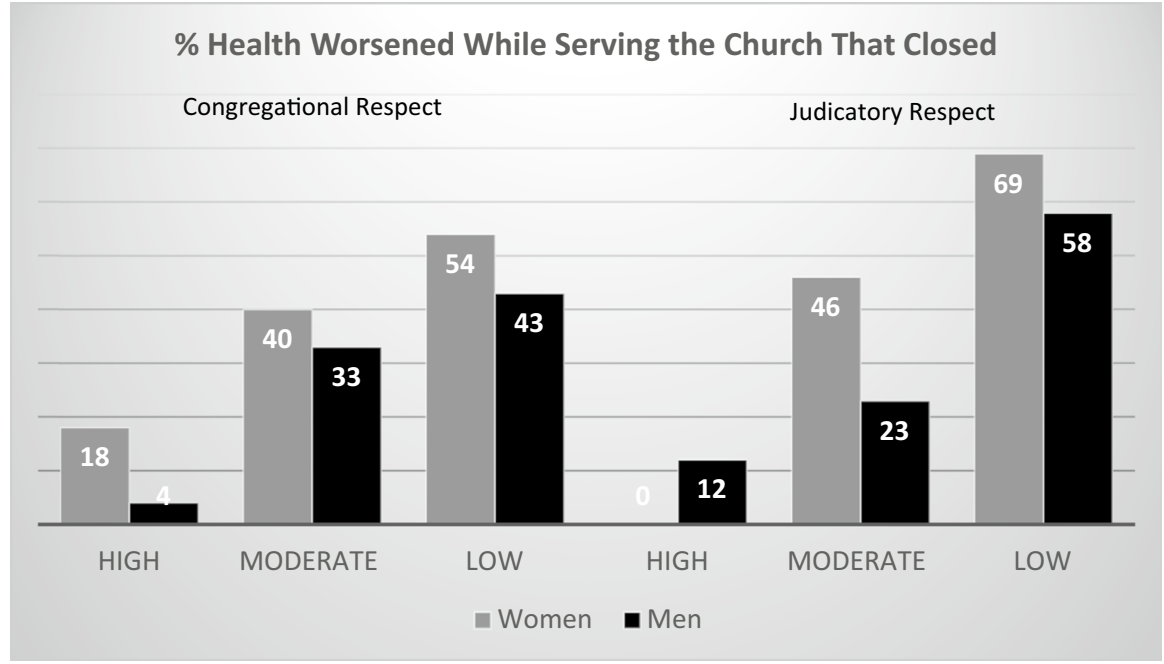

Fig. 2 Reporting their "health worsened" while serving the church that closed by congregational and judicatory respect and gender

Relating to Hypothesis 2, Fig. 3 shows that congregational respect is associated with a less tragic outcome (not Good Friday/Holy Saturday) for women, but not men; judicatory respect decreases the experience of Good Friday or Holy Saturday for both genders. In a logistic regression, gender was not significant. The only significant variables were pastoral stress associated with serving the church that closed, and judicatory respect (Nagelkerke R square $=0.33$ ).

Hypothesis 3 expects that respect from the judicatory might have overall mental health consequences beyond the closure. Zero-order correlations reveal that mental health scores at the time of the survey (1-3 years post-closure) were not related to gender or respect but to age and church experience, stress encountered while serving the church that closed, and also, what happened after the church closed. For example, mental health scores were higher among older clergy $(p<0.01)$, those with better overall physical health $(p<0.001)$. They were also higher for those with more church experience, i.e., not first/second call $(p<0.05)$ and clergy reporting less stress while serving the church that closed $(p<0.05)$. Scores were also higher among clergy not stressed by needing to find a new position $(p<0.01)$, with a lower sense of shame $(p<0.001)$, and with higher satisfaction with personal life and new ministry at the time of the survey (all $p<0.001$ ).

In stepwise regression (Table 3), however, the scale of mental health was significantly related only to pastors' current overall health, and more importantly to satisfaction with current relationships with denominational officials, and with their current life and current ministries. Thus, their current health and context were more important to mental health than the stresses of serving a declining church.

Hypothesis 4 relates respectful relationships with overall vocational stress after the church closed. Table 2 shows that men and women were equally stressed by the need to find another position but significantly more women than men 
Table 3 Standardized regression coefficients: Individual, congregational and judicatory relationships with Self-reported "Health worsened," Loneliness and isolation after closing, Good Friday/Holy Saturday experience, Mental Health after closing, Stress after closing

\begin{tabular}{|c|c|c|c|c|}
\hline Variables & $\begin{array}{l}\text { "Health wors- } \\
\text { ened" when } \\
\text { serving }\end{array}$ & $\begin{array}{l}\text { Good Friday/Holy } \\
\text { Saturday experi- } \\
\text { ence }\end{array}$ & $\begin{array}{l}\text { Mental } \\
\text { health post- } \\
\text { closure }\end{array}$ & $\begin{array}{l}\text { Overall vocational } \\
\text { stress post-closure }\end{array}$ \\
\hline Age & $-0.07 *$ & 0.03 & & $-0.17 * *$ \\
\hline Gender $($ male $=1)$ & & 0.70 & & -1.63 \\
\hline \multicolumn{5}{|l|}{ Married } \\
\hline First/second call & & -0.29 & & \\
\hline Bi-vocational & & & -1.25 & \\
\hline First/second call & & -0.29 & & \\
\hline Multi-church call & & & & $-2.33^{*}$ \\
\hline Positive expectations-self & & 0.94 & & \\
\hline $\begin{array}{l}\text { Positive expectations- } \\
\text { Judicatory }\end{array}$ & & 0.46 & & \\
\hline Congregational respect & $-0.12 * *$ & 0.06 & & \\
\hline Judicatory respect & $-0.08 * *$ & $-0.05^{*}$ & & $-0.12^{*}$ \\
\hline Pastoral Challenges & & -0.02 & & 0.13 \\
\hline Pastoral stress & & $0.20 *$ & & $0.64 * *$ \\
\hline $\begin{array}{l}\text { Perceived health post- } \\
\text { closure }\end{array}$ & & & $1.17 * * *$ & \\
\hline $\begin{array}{l}\text { Satisfaction with life post- } \\
\text { closure }\end{array}$ & & & $0.31 * *$ & \\
\hline $\begin{array}{l}\text { Satisfaction with ministry } \\
\text { post-closure }\end{array}$ & & & $0.60 * * *$ & \\
\hline $\begin{array}{l}\text { Perceived health post- } \\
\text { closure }\end{array}$ & & & $1.17 * * *$ & \\
\hline $\begin{array}{l}\text { Overall vocational stress } \\
\text { post-closure }\end{array}$ & & 0.06 & & \\
\hline $\begin{array}{l}\mathrm{R}^{2} \text { or } \% \text { correctly classified } \\
(\mathrm{N})\end{array}$ & $81 \%(\mathrm{~N}=91)$ & $75 \%(\mathrm{~N}=110)$ & $0.47(\mathrm{~N}=80)$ & $0.56(\mathrm{~N}=84)$ \\
\hline
\end{tabular}

$* p<0.05 ; * * p<0.01 ; * * * p<0.001$

experienced financial strain from losing their position. Women were more likely than men to be single, and therefore unable to rely on a spouse's financial support. Importantly, women clergy are significantly more likely than their male counterparts to perceive signs of stigma associated with a church closing. Four times as many women as men (20\% compared with $5 \%$ ) reported hearing "that closing a church would hinder your search for another position." Moreover, twice as many women pastors as men (18\% compared with $9 \%$ ) "think the experience of closing a church hindered your job search." Women ministers also felt more lonely and isolated than men clergy, which is not surprising given their greater dissatisfaction with respect from the judicatory or wider church when serving their congregation. There were no gender differences in reporting of shame. 


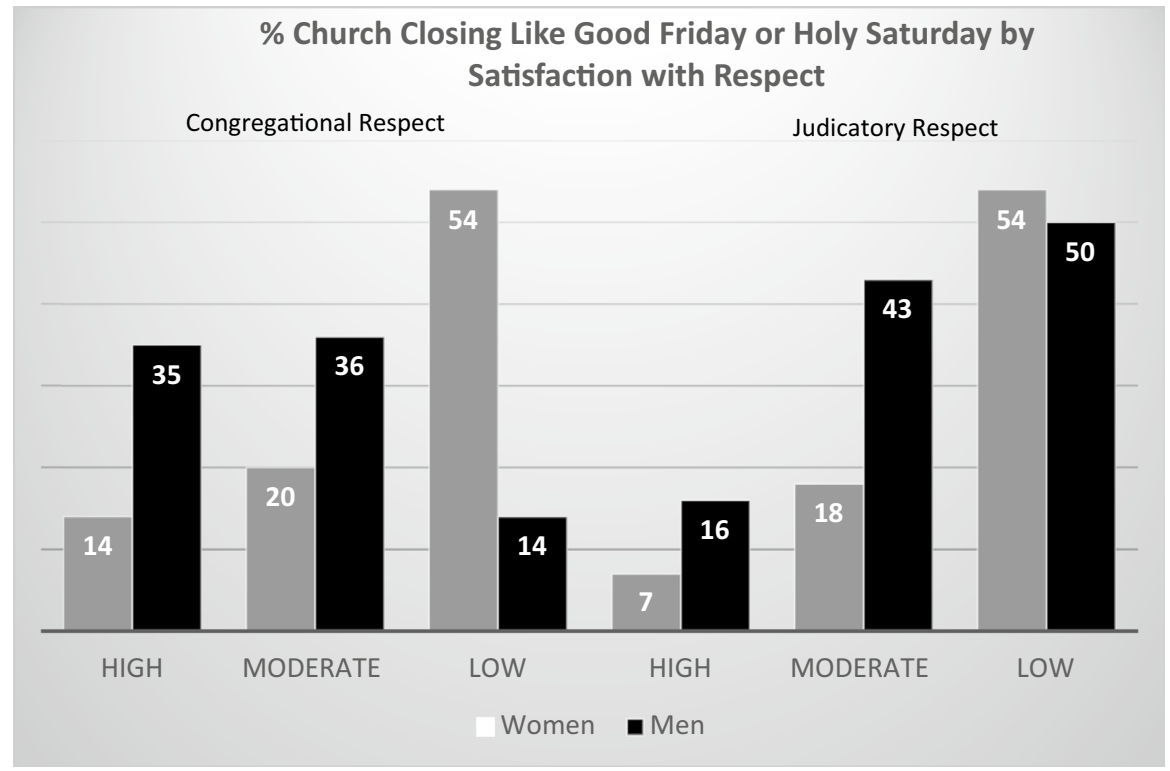

Fig. 3 Reporting a Good Friday/Holy Saturday closing experience by satisfaction with congregational and judicatory respect and gender

Women clergy reported higher overall vocational stress after closing than men $(\mathrm{r}=-0.20, p<0.05)$ but in a stepwise regression (Table 3), younger pastors, those reporting more pastoral stress while serving their churches before closing, and those with lower judicatory respect had higher overall vocational stress. Vocational stress was also significantly less among pastors in a multi-church appointment. Gender is not a significant variable when respect and these other sources of stress and supports are taken into account.

Relating to Hypothesis 5, women experienced greater difficulty than men securing their next position. Figure 4 shows that among men, respect by the judicatory is associated with lower job search time, but for women this does not hold. Although women are more vulnerable financially than men because they are more often single, nearly two-thirds of men clergy found a new pastoral position within the first month, compared with $29 \%$ of women, with an average search for men of 3.4 months, and for women, 7.6 months. The differences are significant $(p<0.01)$ and profound for pastors in a national call system where clergy enter an often-competitive job market (all denominations except the United Methodist Church, which appoints clergy).

Hypothesis 5 suggested that gender differences in satisfaction with judicatory relationships might persist after serving and finding new positions. The study confirmed that women clergy reported less satisfaction than men clergy with relationships with the wider church (denominational officials and other clergy) when the survey was conducted (one to three years after closing). For example, three times as many men (74\%) report they are presently "very satisfied" with denominational officials in their current ministry compared with only $26 \%$ of women $(p<0.05)$. Similarly, nearly six in ten $(71 \%)$ of men clergy reported they are "very satisfied" with 


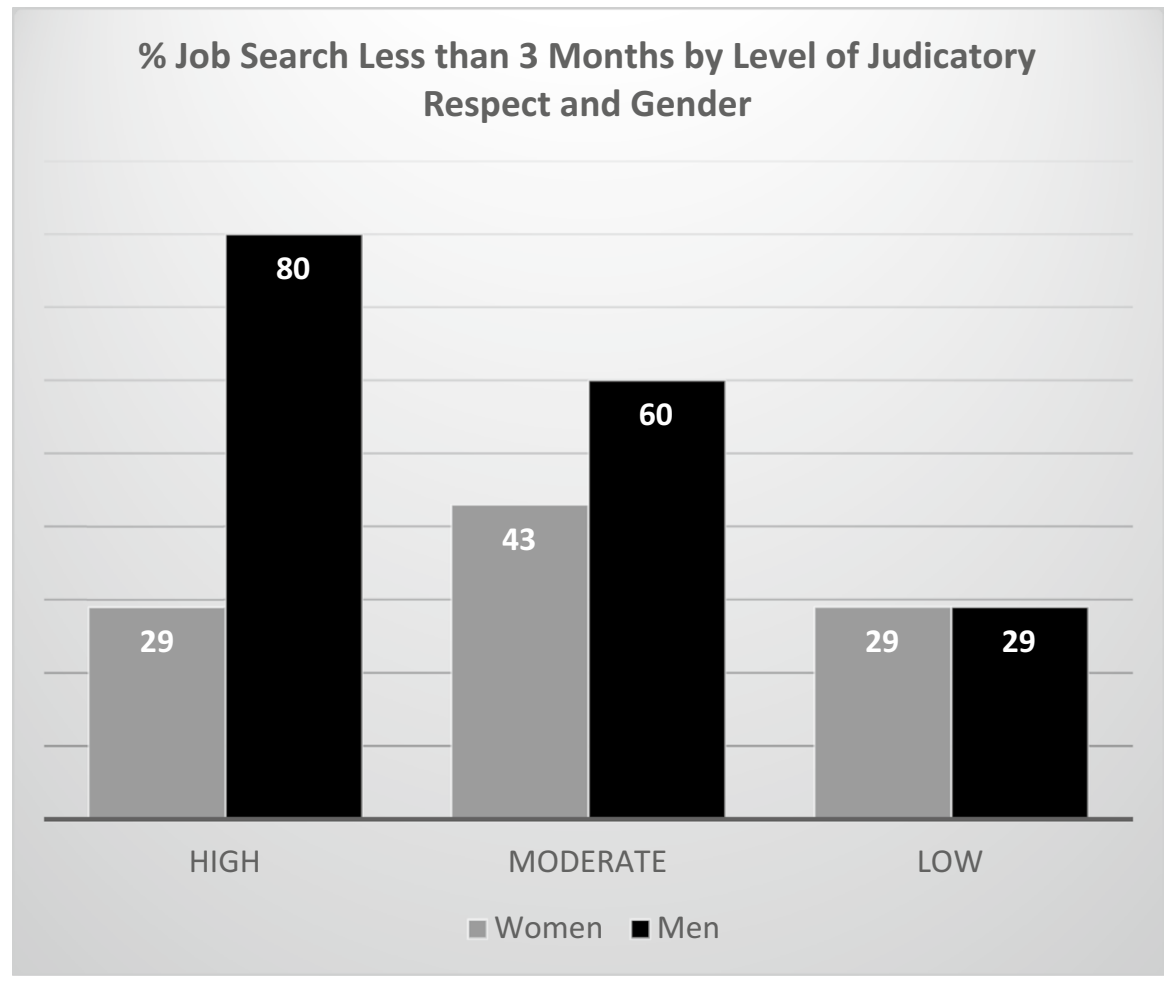

Fig. 4 Reporting a shorter job search by satisfaction with judicatory respect and gender

present relationships with other clergy in their current ministry compared with less than one-third $(29 \%)$ of women $(p<0.05)$. These differences may reflect gender differences in current access to denominational support as well as any difficult experiences serving their churches that closed and vocational transitions.

\section{Discussion}

In the face of economic fallout from the 2020 pandemic, an increasing number of mainline Protestant clergy may serve congregations "on the brink," so challenged by ebbing financial and human resources they will feel called by God to close; some will be closed by the judicatory. This means leading a congregation, and oneself, on a journey into grief and hope of new life. This experience is therefore a crucible for leaders of any gender, a context in which pastors risk loneliness and isolation from colleagues and superiors, feelings of shame, worsened health, and challenges in finding their next position. Previous literature has suggested that mutually supportive relationships with congregations and judicatories, a "living human web," can provide spiritual, material and emotional resources for grieving and stressed pastors. 
The aim of this research was to learn whether these affect vocational and personal outcomes among clergy closing churches, and whether there are gender differences in access to these resources.

This study confirms that being embedded in a mutually respectful living human web of relationships with both congregations and judicatories is related to positive outcomes after a church closes such as less experience of "worsened health" while serving their churches, fewer closing experiences like the mournful season of Good Friday-Holy Saturday, and less overall vocational stress like challenges looking for their next position. Interestingly, mental health appears to be more responsive to the pastor's current context than what happened in the past, that is, to present physical health, and satisfaction with current relationships with the wider church, ministry and personal life. All of these are true for both women and men clergy. Thus a "living human web" of superiors and colleagues may mediate the stress of serving a dying congregation as well as healthy ones.

Vocational stress after closing a congregation is also significantly higher for younger pastors and lower for those in multi-church calls. Younger pastors may lack mutually respectful long-term relationships with colleagues and superiors available to older, more experienced clergy. Surprisingly, younger clergy are more at risk of "worsened health" than older clergy. Perhaps younger pastors are more likely to be blind-sided and hurt by an early career disappointment; in this study, only $20 \%$ of clergy who closed churches entered them expecting to. On the other hand, clergy called to serve more than one church at a time (multi-church appointments) suffer significantly less post-closure vocational stress, possibly because they may continue to serve their "other" congregation(s).

The study also found gender differences in satisfaction clergy colleagues and superiors such as bishops, with greater disappointment among women pastors that judicatories fail to engage in mutually respectful relationships and transformational leadership. This was true as they served their closing churches, and also 1-3 years after their churches closed. As well, the study also found significant gender differences in vocational concerns and trajectories after churches close. Not only are men more likely to find a position in a timely manner than women, with the difference greatest among pastors in a call system (not United Methodist). Women are nearly twice as likely as men to believe that the experience of closing a church affected their job search, that is, to perceive a kind of stigma. This is akin to research findings that women managers and executives in secular occupations perceive persistent gender bias in access to vocational rewards such as esteem, inclusion in decisionmaking, mentoring and networking, and opportunities for advancement.

Secular management literature suggests that stigma may affect a woman's job placement more than a man's because male privilege and expectations of higher male competence pre-empt men from this form of discrimination. In medicine, one study showed that after a patient death, female surgeons experience a greater drop in referrals than male surgeons; after a bad experience with one female surgeon, male surgeons are less likely to refer to any female surgeons. There are no such spillovers to men after a bad experience with a male surgeon (Sarsons 2017). An executive consultant, Joelle Emerson, remarks that, "If women make one mistake, their career gets stalled... Men are able to make multiple mistakes 
and not suffer career consequences" (Lublin 2018). The presumption of superior male competence appears to mediate failure and stigma for men but not for women leaders whether secular or ordained.

One possible consequence of women's difficulty in finding a congregational position in denominations that don't appoint clergy is leaving congregational ministry for another vocation. The written survey confirms that more than twice as many women as men ( $28 \%$ compared with $12 \%, p<0.01)$ have a position following the church that closed that they categorize as "other (than solo or senior pastor, associate or assistant clergy, co-pastor, interim or bridge pastor)." This includes vocations such as hospital chaplain, senior facility chaplain, university chaplain, management of a non-profit, seminary administration, teaching, or work in a secular field.

Although women pastors in subsequent pastoral positions may experience less respect than men from their judicatory, they successfully negotiate leadership challenges by leaning on their faith, family, friends and other supports. For example, the greater the stresses such as health worsening, or a Good Friday closing, the more pastors, both men and women, turned to God for consolation (Cafferata 2020). As well, difficulties women pastors may have experienced in finding their next job such as a lengthier search, or not finding a position at all, which are correlated with mental health, appear to be eased by satisfying relationships with denominational officials, new and current ministries and others such as family, friends and colleagues. In the long run, if faith in God and the living human web of current relationships are strong, the stress of closing a church and a difficult job search appear to be mitigated for both women and for men.

The research raises the question of why respect, a core element of the "living human web," appears weaker for women pastors than for men despite the church's theological commitment to respect the dignity of every human being. For this, scholars may look not only to women's preference for inclusive, transformational leadership but also to structural answers such as cultural bias against female leadership, lack of institutional norms that reflect a commitment to equality and justice for men and women, or theological/geographic/economic cleavages that weaken the capacity of judicatories to understand, trust, or support women pastors in difficult cures. Many judicatories are also historical bureaucracies with inertia or "benign neglect" of past injustices and inequalities. Judicatories led by hierarchical authorities such as bishops run the risk of exercising authority over clergy and congregations in accordance with church law but lacking compassion that transformational pastors of both genders value and expect of their leaders. Further research is needed to explore these possibilities more systematically.

Among the limitations of this study is the relative lack of non-white pastors; this is an opportunity for future research. As well, the research was not designed to examine gender differences in clergy leadership style, although it did allow examination of gender differences in the role of clergy and laity in making the actual decision to close. Further, it was not a longitudinal study, and causal inferences must be taken with caution. Other studies are needed to correct these limitations. 


\section{Conclusions}

Although women have been ordained for decades in every historic Protestant denomination, in this study of closing churches, women clergy report less respect from their denominational bodies_conferences, dioceses, presbyteries and synods-than their male colleagues. Thus, this research confirms previous studies among clergy and other professions showing gendered differences in access to valuable vocational supports and resources. This matters to clergy wellness because respect from peers and denominational superiors decreases untoward personal and vocational consequences such as worsened health, the experience of a tragic "Good Friday" or "Holy Saturday" closing process, financial stress, or an extended or unsuccessful congregational job search. Satisfaction with relationships with current denominational officials when serving in a new call, as well as with new ministries and family life are associated with better well-being following a church's closure. Although the wider church is a sacred community like the congregations that comprise it, its structure as a historical bureaucracy risks compromising its theological commitment to and institutional embodiment of gender equality and justice. How it negotiates those challenges will matter for the increasing number of men and women called to serve and possibly close a church in the coming years.

\section{References}

Bendroth, Norman B. 2018. Interim ministry in action: A handbook for churches in transition. Lanham, MD: Rowman \& Littlefield.

Berry, Amanda, Leslie Francis, Jenny Rolph, and Paul Rolph. 2012. Ministry and stress: Listening to Anglican clergy in wales. Pastoral Psychology 61(2): 165-178.

Brescoll, Victoria L. 2016. Leading with their hearts? How gender stereotypes of emotion lead to biased evaluations of female leaders. The Leadership Quarterly 27(3): 415-428. https://doi.org/10.1016/j. leaqua.2016.02.005.

Cafferata, Gail. 2017. Respect, challenges, and stress among protestant pastors closing a Church: Structural and identity theory perspectives. Pastoral Psychology 66(3): 311-333. https://doi.org/10.1007/ s11089-016-0751-z.

Cafferata, Gail. 2020. The last pastor: Faithfully steering a closing Church. Louisville, KY: Westminster John Knox Press.

Carli, Linda L., and Alice H. Eagly. 2001. Gender, hierarchy, and leadership: an introduction. Journal of Social Issues 57(4): 629.

Carroll, Jackson W. 2006. In God's potters: Pastoral leadership and the shaping of congregations, ed. Becky R. McMillan. Grand Rapids, Mich: William B. Eerdmans Pub.

Chang, Patricia M.Y. 1997. Female clergy in the contemporary Protestant Church: A current assessment. Journal for the scientific study of religion 36(4): 565-573.

Chaves, Mark, and Alison Eagle. 2016. Religious congregations in the 21st century: A report from the National Congregations Study Wave III. http://www.soc.duke.edu/natcong/Docs/NCSIII_report_ final.pdf: Duke University.

Darling, Carol Anderson, E. Wayne Hill, and Lenore M. McWey. 2004. Understanding stress and quality of life for clergy and clergy spouses. Stress \& Health: Journal of the International Society for the Investigation of Stress 20(5): 261-277. https://doi.org/10.1002/smi.1031.

Deutsch, Nancy L., and Jeffrey N. Jones. 2008. "Show me an ounce of respect": Respect and authority in adult-youth relationships in after-school programs. Journal of Adolescent Research 23(6): 667-688.

Dyck, Arthur J. 1977. On human care: An introduction to ethics. Nashville: Abingdon. 
Eagly, Alice H., and Madeline E. Heilman. 2016. Gender and leadership: Introduction to the special issue. The Leadership Quarterly 27(3): 349-353. https://doi.org/10.1016/j.leaqua.2016.04.002.

Ellison, Christopher G., Wei Zhang, Neal Krause, and John P. Marcum. 2009. Does negative interaction in the church increase psychological distress?: Longitudinal findings from the Presbyterian panel survey. Sociology of Religion 70(4): 409-431. https://doi.org/10.1093/socrel/srp062.

Executive Council's Committee on the Status of Women, The, The Church Pension Fund's Office of Research, The Episcopal Church Center's Office of Women's Ministry, and Inc. CREDO Institute. 2009. Called to serve: A study of clergy careers, clergy wellness, and clergy women.

Farley, Margaret A. 1993. A feminist version of respect for persons. Journal of Feminist Studies in Religion 9(1/2): 183-198.

Francis, Leslie J., and Christine E. Brewster. 2012. Stress from time-related over-extension in multiparish benefices. Rural Theology 10(2): 161-178. https://doi.org/10.1558/ruth.v10i2.161.

Francis, Leslie J., Andrew Village, Mandy Robbins, and Keith Wulff. 2011. Work-related psychological health among clergy serving in the Presbyterian church (USA): Testing the idea of balanced affect. Review of Religious Research 53(1): 9-22. https://doi.org/10.1007/s13644-011-0003-8.

Froschauer, Ursula. 2014. South African women ministers' experiences of gender discrimination in the Lutheran Church: A discourse analysis. Feminist Theology 22(2): 133-143. https://doi. org/10.1177/0966735013507851.

Funk, Cary, and Greg Smith. 2012. "Nones" on the rise: One-in-five adults have no religion. In The Pew forum on religion and public life, ed. Louis Lugo. Washington, DC: Pew Research Center.

Gaede, Beth Ann (ed.). 2002. Ending with hope: A resource for closing congregations. Bethesda, MD: Alban Institute.

Gledhill, Ruth. 2015, Jan. 30. Rural vicars struggling with multiple churches and dying congregations. Christian Today.

Goodhew, David. 2017. Facing Episcopal Church Decline. Living Church. Accessed July 25, 2017.

Greene, Anne-marie, and Mandy Robbins. 2015. The cost of a calling? Clergywomen and work in the Church of England. Gender, Work \& Organization 22(4): 405-420. https://doi.org/10.1111/ gwao.12101.

Heilman, Madeline E. 2012. Gender stereotypes and workplace bias. Research in Organizational Behavior 32: 113-135. https://doi.org/10.1016/j.riob.2012.11.003.

Hicks, Donna. 2013. Dignity: Its essential role in resolving conflict. New Haven: Yale university press.

Hoegeman, Catherine. 2017. Job status of women Head Clergy: Findings from the National Congregations Study, 1998, 2006, and 2012. Religions 8(8): 154. https://doi.org/10.3390/rel8080154.

Hughes, Rosalind. 2018. Clergy employment in the Episcopal Church-A new landscape. Accessed August 2, 2018. https://www.episcopalcafe.com/clergy-employment-in-the-episcopal-church-anew-landscape/.

Ibarra, Herminia, and Jennifer Petriglieri. 2015. Impossible selves: Image strategies and identity threat in professional women's career transitions. Fontainebleau, FR: INSEAD.

Irwin, Gail. 2014. Toward the Better Country: Church Closure and Resurrection. Eugene, OR: Resource Publications - An Imprint of Wipf and Stock Publishers.

Lawrence-Lightfoot, Sara. 2000. Respect: An exploration. Cambridge, Mass: Perseus Books.

Lehman, Edward C. 2001. Clergy women's world: Musings of a fox. Review of Religious Research 43(1): 5-13. https://doi.org/10.2307/3512239.

Lerchenmueller, Marc J., and Olav Sorenson. 2017. Research: Junior female scientists aren't getting the credit they deserve. Harvard University. Accessed March 22, 2017. https://hbr.org/2017/03/ research-junior-female-scientists-arent-getting-the-credit-they-deserve.

Lerchenmueller, Marc J., and Olav Sorenson. 2018. The gender gap in early career transitions in the life sciences. Research Policy 47(6): 1007-1017. https://doi.org/10.1016/j.respol.2018.02.009.

Lewis, Christopher Alan, Douglas W. Turton, and Leslie J. Francis. 2007. Clergy work-related psychological health, stress, and burnout: An introduction to this special issue of Mental Health, Religion and Culture. Mental Health, Religion \& Culture 10(1): 1-8.

Lublin, Joanne. 2018. Women managers have little margin for error; one mistake can stall a woman's career, while men's flaws or bad ideas are minimized. The Wall Street Journal (Online), October 19, 2018.

McDuff, Elaine M., and Charles W. Mueller. 1999. Social support and compensating differentials in the ministry: Gender differences in two protestant denominations. Review of Religious Research 40(4): 307-330. https://doi.org/10.2307/3512119. 
McKinney, William. 2012. Crunching the numbers. The Christian Century 129(8): 26-29.

Miller-McLemore, Bonnie. 2018. The living human web: A twenty-five year retrospective. Pastoral Psychology 67(3): 305-321. https://doi.org/10.1007/s11089-018-0811-7.

Olson, Anna B. 2016. Claiming resurrection in the dying church: freedom beyond survival. Louisville, KY: Westminster John Knox Press.

Pargament, Kenneth I. Nalini Tarakeshwar, Christopher G. Ellison., and Keith M. Wulff. 2001. Religious coping among the religious: The relationships between religious coping and well-being in a national sample of presbyterian clergy, elders, and members. Journal for the Scientific Study of Religion 40(3): 497-513.

Parse, Rosemarie Rizzo. 2006. Feeling respected: A parse method study. Nursing Science Quarterly 19(1): 51-56. https://doi.org/10.1177/0894318405283553.

Pepinster, Catherine. 2018. Stressed out Anglican prieststurn to trade unions for support. Religion News Service. Accessed January 17, 2018. http://religionnews.com/2018/01/16/stressed-outanglican-priests-turn-to-trade-unions-for-support/.

Pew Research Center. 2019. In U.S., decline of Christianity continues at rapid pace. Washington, DC: Pew Research Center.

Peyton, Nigel, and Caroline Gatrell. 2015. The Sacrificial Embrace: Exploring contemporary English parish clergy lives. The Expository Times 126(8): 378-388. https://doi.org/10.1177/0014524614 540563.

Pickett, Mallory. 2019. I want what my male colleague has, and that will cost a few million dollars. The New York Times, 44-50, Magazine. https://www.nytimes.com/2019/04/18/magazine/salkinstitute-discrimination-science.html?smid=nytcore-ios-share.

Price, Matthew 2009. Called to serve: A study of clergy careers, clergy wellness, and clergy women.

Proeschold-Bell, Rae Jean, Sara Le Grand, John James, Amanda Wallace, David Toole, and Christopher Adams. 2011. A theoretical model of the holistic health of united methodist clergy. Journal of Religion and Health 50(3): 700-720.

Proeschold-Bell, Rae Jean, and Jason Byassee. 2018. In Faithful and fractured: Responding to the clergy health crisis, ed. Jason Byassee. Grand Rapids, MI: Baker Publishing Group.

Ramsay, Nancy J. 2000. Truth, power, and love: Challenges for clergywomen across the Life Span. In In her own time: Women and developmental issues in pastoral care, ed. Jeanne StevensonMoessner, 269-283. Minneapolis, MN: Fortress Press.

Ridgeway, Cecilia L. 2011. Framed by gender how gender inequality persists in the modern world. Oxford, New York: Oxford University Press.

Ridgeway, Cecilia L. 2014. Why status matters for inequality. American Sociological Review 79(1): 1-16. https://doi.org/10.1177/0003122413515997.

Roozen, David A. 2010. A decade of change in American congregations, 2000-2010.

Rudgard, Olivia. 2017. Pressure to grow congregations leads to 'clergy self-harm' says Christ Church dean. London Telegraph. http://www.telegraph.co.uk/news/2017/11/14/pressure-grow-congregati ons-leads-clergy-self-harm-says-christ/\#.

Sarsons, Heather. 2017. Interpreting signals in the labor market: Evidence from medical referrals. Cambridge, MA: Harvard University.

United Church of Christ, (UCC). 2015. Living legacy: Church legacy and closure resource. Ohio: Cleveland.

van Quaquebeke, Niels, and Tilman Eckloff. 2010. Defining respectful leadership: What it is, how it can be measured, and another glimpse at what it is related to. Journal of Business Ethics 91(3): 343-358. https://doi.org/10.1007/s10551-009-0087-z.

Vial, Andrea C., Jaime L. Napier, and Victoria L. Brescoll. 2016. A bed of thorns: Female leaders and the self-reinforcing cycle of illegitimacy. The Leadership Quarterly 27(3): 400-414. https://doi. org/10.1016/j.leaqua.2015.12.004.

Voas, David, and Mark Chaves. 2016. Is the United States a Counterexample to the Secularization Thesis? 1. American Journal of Sociology 121(5): 1517-1556. https://doi.org/10.1086/684202.

Wespath. 2019. 2017 Clergy Well-Being Survey: Well-Being Survey of The United Methodist Church Active U.S. Clergy-2017. Glenview, IL.

Willimon, William H. 2013, Aug. 1. The tough truth about our small churches. Circuit Rider.

Wuthnow, Robert. 1997. The crisis in the churches: Spiritual malaise, fiscal woe. New York: Oxford University Press. 
Zheng, Wei, Olca Surgevil, and Ronit Kark. 2018. Dancing on the Razor's edge: How top-level women leaders manage the paradoxical tensions between agency and communion. Sex Roles 79(11-12): 633-650. https://doi.org/10.1007/s11199-018-0908-6.

Zikmund, Barbara Brown, Adair T. Lummis, and Patricia M.Y. Chang. 1998. Clergy women: An uphill calling. Louisville, Ky.: Westminster John Knox Press.

Publisher's Note Springer Nature remains neutral with regard to jurisdictional claims in published maps and institutional affiliations. 